\title{
Single-centre epidemiological study on the incidence of hepatic hydatid cyst
}

\author{
DANIELA ELENA MIHĂILĂ $\breve{1}^{1}$, T. D. POTEC $\breve{A}^{1,2}$ ANCA POTEC $\breve{A}^{1}$, S. PIȚURU ${ }^{1}$ \\ "“Carol Davila" University of Medicine and Pharmacy, \\ 37 Dionisie Lupu Street, 020022, Bucharest, Romania \\ “'Colentina” Clinical Hospital, 19-21 Ştefan cel Mare Street, 72202, Bucharest, Romania
}

\begin{abstract}
Echinococcosis is a parasitic disease caused by Echinococcus granulosus tapeworm through its larva infestation. Hydatid cyst has become a health problem interesting by the demographic changes in recent years. If until recently it was a disease of the pastors or breeders and animal lovers in rural areas, the increase in number of the stray animals in the streets of big cities has moved the curve incidence and prevalence of this disease onto the city. Worldwide pathology is prevalent in the Mediterranean, South America and Turkey. The present study examines patients admitted with the diagnosis of hydatid cyst in the surgery department of Colentina Clinical Hospital, Bucharest, across a period of six years. The results demonstrate that the incidence is higher among women $(58 \%)$ than in men $(41.3 \%)$. Also, statistical data processing shows that the prevalence/incidence is higher in urban areas compared to rural areas. We want the results of this research to lead to hypotheses that can be demonstrated by analytical studies, because, without fundamental knowledge provided by descriptive studies, it is almost impossible to ask about the aetiology and effects of treatments that can be used in the management of hydatid cyst.
\end{abstract}

Key words: incidence, Echinococcus granulosus, Romania.

\section{INTRODUCTION}

The concern for this pathology dates from ancient times and has evolved with advances in modern medicine. Studies to find new methods of diagnosis, treatment or prevention (vaccine EG95 trial in 2012, under the auspices of WHO - to protect intermediate hosts) occur worldwide and growing controversies in these areas emerge [1].

Hydatidosis, caused by dog tapeworms of the genus Echinococcus, is one of the most important cestode infections of man. It is widely distributed and recent information points to a spread of the disease into areas previously free of it. This article reviews recent advances in understanding the biology of Echinococcus, relating these developments to the epidemiology of hydatid disease and its control. The hydatid cyst always starts as a fluidfilled, cyst-like structure (Type I) which may proceed to a Type II lesion if daughter cysts and/or matrix develop [2].

According to Matossian, Rickard and Smyth (1977) attention is drawn to the urgent need for measures to prevent the importation of infected livestock and this would require the development of techniques for pre-mortem diagnosis and differentiation of hydatidosis and cysticercosis of animals [3]. Cystic echinococcosis (CE) is an emerging zoonotic parasitic disease throughout the world. Human incidence and livestock prevalence data of CE were gathered from published literature and the Office International des Epizooties databases. Preoperative recognition is important for planning an appropriate surgical treatment in avoiding complications. Biliary fistulae are the most feared complication of hepatic hydatidosis operators and techniques used to prevent/ cure them are nonstandardized, variable, numerous and controversial [4]. For the correct treatment, a correct diagnosis is primarily needed. The appearance of biliary-cystic communication is valued at $80-90 \%$ and clinical incidence is only about $30 \%$ [5].

\section{MATERIAL AND METHOD}

\section{SAMPLE}

The research was conducted on a total of 142 subjects aged between 20 and 80 years, from 22 counties. Of all subjects, 83 were female, representing a frequency of $58 \%$, and 59 male, with a frequency of $42 \%$ (Table 1 ). The study was conducted in the period 2007-2012, in Colentina Clinical Hospital, Department of Surgery. 


\section{STUDY VARIABLES}

The study variables were represented by: gender, age, type of surgery, the patient's county of residence.

\section{CRITERIA FOR INCLUSION IN THE STUDY}

In the present study, there were included patients admitted, investigated and operated at Colentina Clinical Hospital in the period 2007-
2012, with the diagnosis of hepatic hydatidosis. Among the selected cases, there were patients with multiple locations parasitosis, interventions being more complex in their case and targeting other organs than the liver.

\section{RESULTS}

Data were analysed with two statistical analysis software programs: Epi Info, namely SPSS version 18.

Table 1

Frequency table - patient's gender

\begin{tabular}{llcc}
\hline & & Frequency & Percent \\
\hline Valid & Female & 83 & 58.0 \\
& Male & 59 & 41.3 \\
& Total & 142 & 99.3 \\
\hline
\end{tabular}

Table 2

Frequency table - incidence of hydatid cyst of the liver in given counties

\begin{tabular}{llcc}
\hline & Frequency & Percent \\
\hline Valid & Bucureşti & 23 & 16.1 \\
& Ialomița & 29 & 20.3 \\
Dolj & 2 & 1.4 \\
Ilfov & 6 & 4.2 \\
Galați & 2 & 1.4 \\
Călăraşi & 10 & 7.0 \\
Vrancea & 10 & 7.0 \\
Teleorman & 5 & 3.5 \\
Buzău & 9 & 6.3 \\
Giurgiu & 7 & 4.9 \\
Constanța & 3 & 2.1 \\
Suceava & 2 & 1.4 \\
Dambovița & 5 & 3.5 \\
Vaslui & 3 & 2.1 \\
Argeş & 10 & 7.0 \\
Brăila & 4 & 2.8 \\
Olt & 5 & 3.5 \\
Braşov & 2 & 1.4 \\
Tulcea & 1 & .7 \\
Prahova & 2 & 1.4 \\
Bacău & 1 & .7 \\
Gorj & 1 & .7 \\
Total & $\mathbf{1 4 2}$ & $\mathbf{9 9 . 3}$ \\
\hline
\end{tabular}

Regarding the surgical treatment of the hydatid cyst, classical techniques (cystectomy with drainage cavity, pericystectomy and digestive anastomosis) were elected, with proven effectiveness [6] also in countries with tradition in the treatment of hydatidosis [7]. Considering the premise that the gallbladder is a continuous reservoir of parasitic infection, when determining intraoperatively that there are no contraindications, cholecystectomy is performed and associated to procedures with curative aim directed to the cyst. We see that in our group $30 \%$ of patients underwent cholecystectomy.
Although the omentoplasty is practiced in other centres [8], in the group studied this technique is adopted in only 10 cases, the remaining 120 patients having only external drainage of residual cavity. The main postoperative complication recorded was biliary fistula, in 50 patients, its occurrence increasing the period necessary to keep the remaining cavity drainage tube in situ.

Also, clinical predictors should be considered for early diagnosis and proper management of intrabiliary ruptures in patients with hepatic hydatid cysts [9]. 


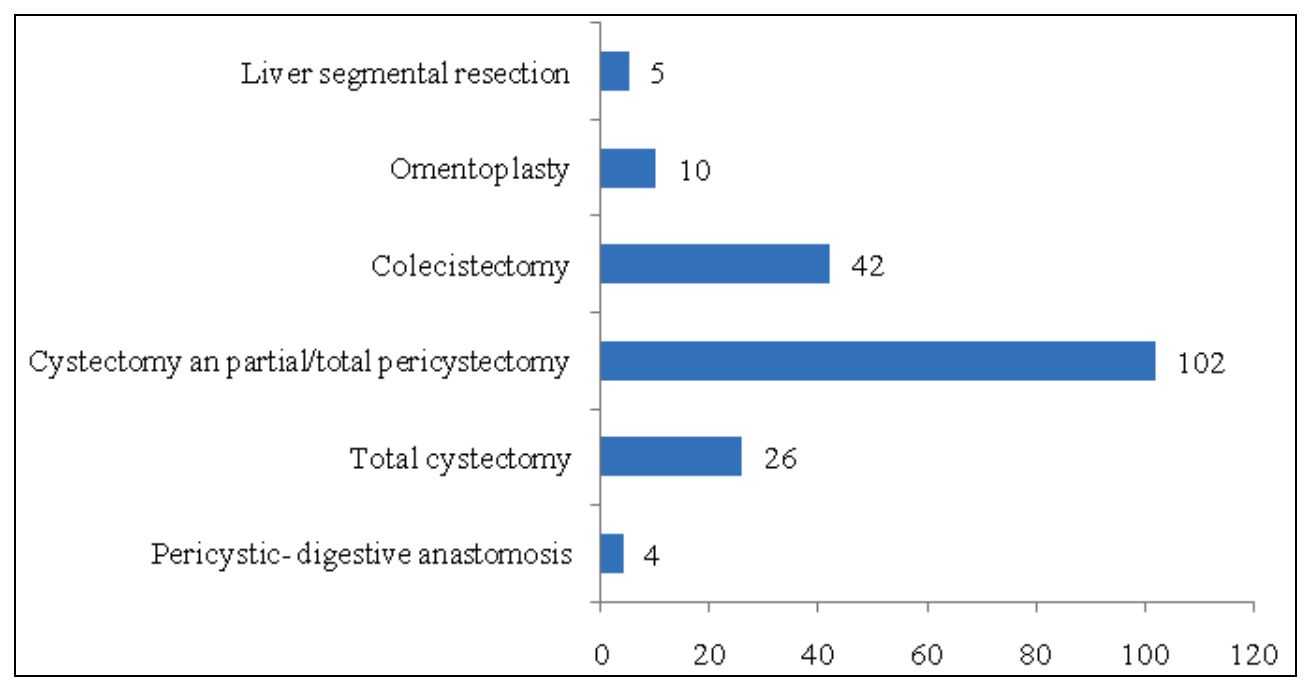

Fig. 1. Number of cases per type of procedure.

\section{DISCUSSION AND CONCLUSIONS}

Echinococcus granulosus causes cystic echinococcus in humans, a condition that is found throughout the world and is endemic in large sheepraising areas in Europe, Asia, the Mediterranean, South America and Northern Kenya. With immigration, the prevalence of the disease has increased in Europe - it has doubled in the last 5 years (ECDC, 2013) and North America [10]. Also, in Turkey, the prevalence of E. granulosus infection in dogs is between 0.32 and $40 \%$ and varies widely with geographical location. The reported prevalence of CE in domestic animals in Turkey has ranged from 11.2 to $50.7 \%$ and has varied widely with geographical location [11].

Regarding our country, it is found that the highest incidence of the hydatid cyst is among female subjects (Table 1). Table 2 shows the counties with high frequency: Ialomita (29 cases, with a rate of $20.3 \%$ and a cumulative percentage of $36.6 \%$ ) and Bucharest (23 cases, with a frequency of $16.1 \%$ and a cumulative percentage of $16.2 \%$ ), followed by Vrancea and Călăraşi, where the frequency is 10 cases (representing 7.0\%). The lowest incidence is found in the counties of Tulcea, Bacau and Gorj, with a frequency of 1 case of all subjects.

Due to the socio-economic and topographic evolution of the past decades, the incidence of this disease has moved to big cities, its primary cause being the increasing number of stray animals that live in urban areas and serve as final host for the parasite.

The clinical implications of the hydatid disease at different stages are discussed. A plea is made for the development of an international medical hydatid registry employing uniform nomenclature and consistent reporting, in order to allow more rational comparisons of different types of management [2]. Conservative therapies - drugs (albendazole, praziquantel), PAIR - are effective in cases carefully selected, with small cysts and patients with no significant comorbidities, which limits the applicability of these methods.

Diagnosing patients in the early stages and multimodal therapy can significantly improve survival and quality of life for patients. The curative treatment remains the surgical one, with the necessary economic and social implications. Also, the finding of a population at risk and initiating targeted information campaigns and prevention could help decrease the number of new cases.

In conclusion, we want the results of this research to lead to hypotheses that can be demonstrated by testing and analytical studies, because without fundamental knowledge provided by descriptive studies, it is almost impossible to ask about the aetiology or effects of the treatments used in the management of hydatid cyst. At the EU level, there is little epidemiological data related to echinococcus in our country, which means we need to centralize and improve the existing data reported from surgical and parasitological centres nationwide. Moreover, the study provides information that can be used by decision makers at the national level in the implementation and enhancement of policies to prevent dissemination of the parasites in both the centres of human medicine and veterinary medicine.

Acknowledgement. This paper is supported by the Sectoral Operational Programme Human Resources Development (SOP HRD), financed from the European Social Fund and by the Romanian Government under the contract number POSDRU/159/1.5/S/137390. 
Echinococoza este o parazitoză cauzată de Echinococcus granulosus prin infectarea gazdei cu larva. Chistul hidatic a devenit o problemă majoră de sănătate publică datorată modificărilor demografice din ultimii ani. Dacă înainte era prezentă cu precădere în rândul populației rurale, creşterea numărului câinilor comunitari din marile oraşe a mutat creşterea incidenței şi a prevalenței bolii înspre zonele urbane. Boala este mai ales prezentă in zona mediteraneană, America de Sud şi Turcia. Studiul a analizat pacienții internați în cadrul secției de chirurgie a Spitalului Clinic Colentina cu diagnosticul de chist hidatic pe o perioadă de 6 ani. Rezultatele au arătat o incidență mai mare la femei (58\%) decât la bărbați (41.3\%). Totodată analiza statistică a demonstrat că incidența şi prevalența sunt mai mari în mediul urban decât în mediul rural. Studiul descriptiv prezentat se doreşte a fi premiza unor studii analitice ulterioare care să evalueze etiologia şi efectul tratamentului în managementul chistului hidatic.

Corresponding author: Teodor Dan Potecă, "Carol Davila” UMF

E-mail: Anca_poteca@yahoo.com

The authors declare no conflict of interest.

\section{REFERENCES}

1. WHO. Inform working group on echinococcosis. International classification of ultrasound images in cystic echinococcosis for application in clinical and field epidemiological settings. Acta Trop. 2003; 85(2):253-261.

2. LEWALL D.B. Hydatid disease: biology, pathology, imaging and classification. Clinical Radiology.1998; 53(12):863-874.

3. MATOSSIAN R.M, RICKARD M. D., SMYTH, J.D. Hydatidosis: A global problem of increasing importance. Bulletin of the World Health Organization.1997; 55(4):499.

4. PÎRŞCOVEANU M., MUNTEANU M., MĂNESCU P., ANCA R., VASILE L. Therapeutic problems in complicated liver hydatid cyst. Current Health Sciences Journal. 2010; 36(4). http://www.chsjournal.org/archive/vol36-no4-2010/originalpapers/therapeutic-problems-in-complicated-liver-hydatid-cyst-title.

5. KAPOOR S., NUNDY S. Bile duct leaks from the intrahepatic biliary tree: A review of its aetiology, incidence and management. HPB Surgery, 2012 http://www.ncbi.nlm.nih.gov/pmc/articles/PMC3356893/

6. JABBOUR N., SHIRAZI S. K., GENYK Y., MATEO R., PAK E., COSENZA, D.C., et al. Surgical management of complicated hydatid disease of the liver. Am Surg.2002; 68(11):984-988.

7. DAWSON J.L., STAMATAKIS J.D., STRINGER M.D., WILLIAMS R. Surgical treatment of hepatic hydatid disease. Br J Sur. 1998; 75: 946-950.

8. TOLGA MUfTUOGLU M. A., KOKSAL N., TOPALOGLU U. The role of omentoplasty in the surgical management of remnant cavity in hepatic hydatid cyst. HPB (Oxford). 2005; 7:231-234.

9. 9 ATLI M., KAMA N.A., YUKSEK YN., DOGANAY M., GOZALAN U., KOLOGLU M., et al. Intrabiliary rupture of a hepatic hydatid cyst: associated clinical factors and proper management. Archives of Surgery. 2001; 136(11): 1249-1255.

10. KHUROO M. S., WANI N. A., JAVID G., KHAN B. A., YATTOO G. N., SHAH A.H, et al. Percutaneous drainage compared with surgery for hepatic hydatid cysts. New England Journal of Medicine. 1997; 337(13), 881-887.

11. AltinTAS N. Past to present: echinococcosis in Turkey. Acta Tropica. 2003; 85(2):105-112. 